\title{
Farmers' Preference of Cassava (Manihot esculenta Crantz) Varieties Introduced to Improve Plant Productivity in North Sumatra Province, Indonesia
}

\author{
Yudi Widodo ${ }^{1}$, Ruly Krisdiana ${ }^{1}$, Nila Prasetiaswati ${ }^{1}$, Kartika Noerwijati ${ }^{1}$, \\ Arief Harsono', Didik Sucahyono ${ }^{1}$, Tinuk S. Wahyuni ${ }^{1}$, Titik Sundari ${ }^{1}$, \\ Made J. Mejaya ${ }^{1 *}$, Martias ${ }^{2}$ and I. G. K. D. Arsana ${ }^{3}$ \\ ${ }^{1}$ Indonesian Legume and Tuber Crops Research Institute (ILETRI), Jl. Raya Kendalpayak Km 8, PO \\ Box 66 Malang 65101, East Java, Indonesia. \\ ${ }^{2}$ Indonesian Tropical Fruits Research institute, Indonesia, Jl. Raya Solok-Aripan Km. 8, Solok 27301, \\ West Sumatra, Indonesia. \\ ${ }^{3}$ Bali Agricultural Technology Assessment Institute, JL. By Pass Ngurah Rai, Denpasar, Bali 80222, \\ Bali, Indonesia.

\section{Authors' contributions} \\ This work was carried out in collaboration among all authors. Authors YW, RK, KN, TS and MJM \\ designed the study. Authors YW, NP, KN, and AH performed the statistical analysis and wrote the \\ protocol. Authors YW, RK, KN, DS and MJM wrote the first draft of the manuscript. Authors YW, TS \\ and MJM managed the analyses of the study. Authors YW, KN, TSW, IGKDA, M and MJM managed \\ the literature searches. All authors read and approved the final manuscript.
}

Article Information

DOI: $10.9734 / A R R B / 2021 / v 36 i 930422$ Editor(s):

(1) Dr. Bechan Sharma, University of Allahabad, India. Reviewers:

(1) Makaza Kasirayi, Great Zimbabwe University, Zimbabwe. (2) Abdul Jafari Shango, World Vegetable Center, East and Southern Africa. Complete Peer review History: https://www.sdiarticle4.com/review-history/73351

Original Research Article

Received 24 June 2021 Accepted 04 September 2021 Published 10 September 2021

\section{ABSTRACT}

A varietal testing had been undertaken in Pematangsiantar regency, North Sumatra province, Indonesia in 2015-2016. The objective of the study was to determine the preference of cassava growers to the introduced varieties compared to the existing cassava varieties. Twelve cassava varities (UB1/2, UB1472, Adira1, Malang4, Cecekijo, Farsem, Gajah, Ketan Jabung, Caspro, Malaysia, Adira4, and Cikaret) were tested using a Randomized Block Design with four replications. The data were taken on aboveground characters and underground characters such as 
root number, root diameter, root length, root weight, and starch content based on factory criteria (A $=22 \%, \mathrm{~B}=18 \%, \mathrm{C}=14 \%$ and $\mathrm{D}=10 \%$ starch content). Results of the study indicated that Malang-4 had the highest root yield $\left(49,830 \mathrm{~kg} \mathrm{ha}^{-1}\right)$ followed by Farsem variety $\left(41,690 \mathrm{~kg} \mathrm{ha}^{-1}\right)$, and Malaysia Local variety $\left(41,030 \mathrm{~kg} \mathrm{ha}^{-1}\right)$. The bitter taste of Malang 4 was an appropriate character to be developed as starch processing of cassava. Starch content is very important indigenous criteria for farmers and traders to know fairly about pricing in relation with starch content. The higher starch content coincided with higher root yield of Malang-4 is very interesting and will benefit the factory. There was no difference in factory price of cassava from farmers, although the starch content indicated different levels $(B=18 \%, C=14 \%$ or $D=10 \%)$. The Malang- 4 could be introduced to the local goverment for being grown in a larger areas in the North Sumatera province.

Keywords: Preference; cassava growers; introduced varieties; root yield; variety.

\section{INTRODUCTION}

Cassava (Manihot esculenta Crantz) is a third staple food as a carbohydrate source after rice and maize in Indonesia. Therefore it plays an important role in food security of a region. Cassava has a fairly good nutritional value and is very necessary to maintain a healthy body, as food, especially as a source of carbohydrates. The resulting tubers contain about $60 \%$ water, $25 \%-35 \%$ starch, and protein, minerals, fiber, calcium, and phosphate. Cassava can also be used as animal feed and industrial raw materials. Therefore, the development of cassava is very important in the effort to provide non-rice carbohydrate food, diversification of local food consumption, development of the product processing industry and agro-industry and as a source of foreign exchange through exports as well as efforts to support increased food security and food self-sufficiency [1].

The expansion of cassava production area is directed to the outside of Java island, such as North Sumatra which is one of a progressive province in Indonesia where cassava is grown widely by farmers especially as source of income. With the wet tropical climate, the huge upland in North Sumatra is very suitable for cassava production all year round due to adequate rainfall of 8-10 wet months [2]. The better price of cassava from 2010 to 2015 triggered many farmers as well as income speculator to grow cassava in large area. Interestingly cassava development area in the whole of North Sumatra was increased dramatically. In fact cassava development area encroached into oil palm and rubber plantation as well.

The area of cassava development also goes to upland areas in higher altitudes such as in Prosea under District of Toba Samosir. Around
Lake of Toba there is still an abundance of land under fallow condition which is utilized by investor for growing cassava [3]. Unfortunately those areas are located in the altitudes exceeding $1200 \mathrm{~m}$ above sea level, consequently growth and yield of cassava takes a longer period and considered not profitable and ultimately cassava development in those areas is not sustained [4]. However, if the new high yielding variety of cassava suitable for higher altitude are available the sustainability can be expected. As a follow up of the scoping study in 2014 , a variety trial as preliminary study under value chain management of cassava was planted at small plantation of PT. Bumi Sari Prima with farmers and traders participation. In North Sumatra, Pematangsiantar is the second largest city after Medan. In the Municipal of Siantar there is a huge tapioca factory which belongs to PT. Bumi Sari Prima. Cassava harvested from Pematangsiantar, Simalungun, Prosea and Serdang Bedagai is also send to tapioca factory in Pematangsiantar.

In attempts to gain high productivity and income, the new innovation technology is urgently required by cassava growers. The newly technology especially new improved variety is important for farmers to increase root yield productivity. The new cassava variety developed and released for industrial use, particularly for starch production could increase the fresh and dry root yields of $39 \%$ and $44 \%$ higher, respectively, than those of local varieties. The root quality traits allowed the extraction of highquality starch. Therefore, the role of improved cassava variety adapted to a certain soil condition combined with many kinds of cultural practice is very important $[5,6]$.

PT. Bumisari Prima one of Tapioca big scale factory in Siantar, is importing the new cassava 
varieties from ILETRI in Malang for multiplication, which gradually will be distributed to farmers with traders medium. An awesome amount of Malang-4 was bought by PT. Bumi Sari Prima from ILETRI. The indigenous criteria used by cassava growers were studied. However in cassava development progress there is a problem which is not in a researchable area, namely price. Price can be fairly decided between farmers and processor, by wishing from support of local government. With regards to value chain management oriented research as initiated by UQ-ACIAR-CIAT-ILETRI-UB, a varietal testing had been undertaken with the objective to study the preference of cassava growers to the existing cassava varieties compared to the newly introduced varieties.

\section{MATERIALS AND METHODS}

\subsection{Study Site}

The field study was conducted in Pematangsiantar regency, North Sumatra province, Indonesia in 2015-2016. The latitude of location was 2.970042 and the longitude was 99.068167 with an altitude of 381 meters above sea level.

\subsection{Soil Sampling and Analysis}

Three soil samples were taken randomly from the location of evaluation for laboratory analysis at the Soil Laboratory Faculty of Agriculture, University of Brawijaya (UB) Malang in 2015. The soil was analyzed for acidity by measuring $\mathrm{pH}$, soil organic matter and its nutrient contents $(\mathrm{N}$, $\mathrm{P}, \mathrm{K}, \mathrm{Ca}, \mathrm{Mg}$ and $\mathrm{Al}$ ).

\subsection{Planting Materials and Experimental Design}

\subsubsection{Description of planting materials}

Twelve cassava varities consisted of 10 improved varieties (UB1/2, UB1472, Adira1, Malang4, Cecekijo, Farsem, Gajah, Ketan Jabung, Caspro, and Adira4) and two local varieties (Malaysia and Cikaret). The improved varieties were derived from Brawijaya University as the results of CIAT-UB-IDRC-ILETRI in the period of 1985-2005 and national released varieties from ILETRI. The two local varieties were widely planted by farmers in Pematangsiantar which was the location of the study.

\subsubsection{Experimental design}

A Randomized Block Design with four replications was adopted for undertaking this field experiment.

\subsubsection{Crop establishment and management}

Stem cuttings with $25 \mathrm{~cm}$ length were planted in the spacing of $100 \mathrm{~cm} \times 100 \mathrm{~cm}$ in the plot size of $5 \mathrm{~m} \times 5 \mathrm{~m}$. So population of each plot was 25 plants, however plot net for harvest was only 9 plants (avoiding border effects), and remaining 16 plants as border in each plot. Planting was carried out at December 2015 and harvesting was undertaken at 25-28 October 2016, at the period of around 10 months after planting. It was planted in November 2015 and harvested at 10 months on late of September 2016. Organic MABAR was applied as basal fertilizer entirely at rate of $50 \mathrm{~kg}$ in each replication, so required $200 \mathrm{~kg}$ for four replications. Basal fertilizer application was done immediately after planting of stem cutting in the same day. At two weeks after planting, first fertilizer application was applied with compound fertilizer Phonska NPKS $=15: 15: 15: 10$, at amount of $2.1 \mathrm{~kg} / \mathrm{plot}$ or $25 \mathrm{~kg}$ Phonska/replication or $100 \mathrm{~kg}$ Phonska for whole plots in four replications. At 1.5 months after planting the second fertilizer was applied in a form of Urea $12.5 \mathrm{~kg} /$ replication or $50 \mathrm{~kg}$ for whole plots in four replications. At three months after planting the third fertilizer application was practiced in a form of compound Mutiara fertilizer with NPK $=16: 16: 16$ at amount of $12.5 \mathrm{~kg}$ Mutiara/replication or $50 \mathrm{~kg}$ for whole plots in four replications. Application of Mabar organic fertilizer by put properly around stem cutting position, and inorganic fertilizer put into holes then covered by soil to avoid leaching, leaking and volatile.

Chemical weeding by spraying herbicide Gramoxone 2 I for whole area of 0.25 ha was undertaken before land preparation. Four wheel tractors with attachment of tools were used to prepare soil from plowing, harrowing and ridging. Hand weeding was done twice, before second and third fertilizer applications. So the cassava plantation was relatively well maintained and free from weed interferences as well. Pest and disease observed during harvesting which was undertaken at 10 months after planting. The second fertilizer application was undertaken at around three months after planting, in the form of 
half dosage of Urea and $\mathrm{KCl}$ as well. In organic fertilizers applied early then followed by organic manure to cover inorganic fertilizer, in the following days hilling up was subsequently done properly with second weeding.

\subsubsection{Participatory evaluation}

Participatory evaluation of cassava variety trial was adapted to measure the consumer preference based on plant performance especially root yield and starch content. Selection criteria applied by 30 farmers, five traders and one factory staff during the harvest of variety trial on 24-26 October 2016.

\subsubsection{Data observed and analysis}

Cassava was harvested after ten months old by digging the soil manually. The data were taken on aboveground characters (plant height, branching height, Stem diameter, Stem and leaves weigth per plant (on basal, middle, and upper parts of stem) as well as underground characters (root number, root diameter, root length, root weight, and starch content). Root weight each variety was based on the plot size of $3 \mathrm{~m} \times 3 \mathrm{~m}$ and then it was converted into hectares. Starch content was based on factory criteria $(A=22 \%, B=18 \%, C=14 \%$ and $D=$ $10 \%$ starch content). The data collected from agronomic observations were analized using MSTATC by indicating Coefficient of Variation (CV) and mean separation by Least Significant Difference (LSD 5\%).

\section{RESULTS}

\subsection{Soil Analysis}

The soil laboratory analysis indicated that experimental site had an acid soil reaction with $\mathrm{pH}$ ranging from 4.3 to 4.5 . The content of soil organic matter 1.76 to $2.16 \%$ is categorized at low to medium level, so do the content of Nitrogen $(\mathrm{N}) 0.08$ to $0.12 \%$, Phosphorus $(\mathrm{P}) 3.78$ to $4.04 \mathrm{ppm}$, Potassium (K) 0.14 to 0.23 me.100 $\mathrm{g}^{-1}$, Calcium (Ca) 0.76 to $0.87 \mathrm{me}^{100 \mathrm{~g}^{-1} \text { as well }}$

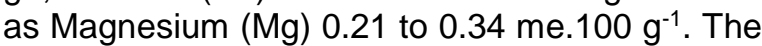
Aluminum 1.98 to $2.11 \mathrm{me}^{1} 100 \mathrm{~g}^{-1}$ is not high but at medium level (Table 1).

Indeed for cassava this kind of soil chemistry condition was not too problem, due to cassava was able to grow and produce yield under soil $\mathrm{pH}$ below than 4. It was one of an advantage of cassava as pioneer food crop. However in order to maintain soil fertility and attain better cassava growth and yield, the recommendation of fertilizer application based on this laboratory analysis by applying manure 5 to 10 t.ha $^{-1}$, lime at amount of 300 to $400 \mathrm{~kg} \cdot \mathrm{ha}^{-1}$. Both manure and lime is applied at planting in around stem cutting position. As source of $\mathrm{N}$, Urea $300 \mathrm{~kg} \cdot \mathrm{ha}^{-1}$ equal to $135 \mathrm{~kg} \mathrm{~N}$.ha-1 was split into twice application at planting till 30 days after planting and 3 months. The amount of $100 \mathrm{~kg} \mathrm{SP} 36$ equal to $30 \mathrm{~kg}$ $\mathrm{P}_{2} \mathrm{O}_{5} \cdot \mathrm{ha}^{-1}$ was entirely applied at early after planting together with manure and lime as well. As source of $\mathrm{K}, 200$ to $300 \mathrm{~kg} \mathrm{KCl}^{-h a^{-1}}$ equal to 100 to $150 \mathrm{~kg} \mathrm{~K}_{2} \mathrm{O} \cdot \mathrm{ha}^{-1}$ was also split into twice application and together with Urea.

This site was also planted by cassava regularly year round; therefore soil organic matter was so low due to no additional manure applied previously. Meanwhile harvesting cassava was by removing entire plant out from the plot. So very small portion of cassava plant was returned back to soil, consequently soil organic matter becoming gradually reduced and ultimately low. An existing farmers' practice to maintain soil organic content was by letting the litter of crops and weeds incorporated into soil during land preparation. Commonly farmers let weeds grew amid of cassava crop at the end of growing period. Sometimes during harvest to be more difficult due to serious and excessive weed growth. Spraying contact herbicide 1-3 days before harvest was common way to make harvest easier. Cassava growers keen that weed killed by herbicides contribute organic matter into soil. A fallow period in between harvest and further planting also provide space for weed to recover and grow, therefore additional herbicides application was required. The adequate rainfall was also as indicator that leaching process was very intensive, although this sandy soil from volcanic eruption in the ancient period however $\mathrm{pH}$ was low factually.

\subsection{Cassava Yield Performance}

Among the 12 varities tested, Malang4 variety had the highest plant height with almost no branching till at height above $2.5 \mathrm{~m}$. It means this type of cassava was suitable to be grown under intercropping, so associate crops will not be suffered due to shade of cassava canopy. The other introduced varieties such as UB1/2, UB1472, Adira-1, Farsem and Caspro also indicated as the late branching types which possible to be considered for intercropping base, except Kejab and Gajab. From field observation indicated an uncommon phenomenon in branching or forking formation for 12 varieties evaluated, with exception to Malang-4. 
Table 1. Results of soil sample analysis taken from Pematangsiantar, 2015-2016

\begin{tabular}{|c|c|c|c|c|c|c|c|c|}
\hline \multirow[t]{2}{*}{ Soil sample } & \multirow[t]{2}{*}{$\mathrm{pH}$} & $\begin{array}{l}\text { Organic } \\
\text { matter }\end{array}$ & $\mathbf{N}$ & $\mathbf{P}$ & $\mathrm{K}$ & $\mathrm{Ca}$ & Mg & \multirow[t]{2}{*}{ Al } \\
\hline & & (\%) & & Ppm & \multicolumn{2}{|c|}{$\left(\mathrm{Me} 100 \mathrm{~g}^{-1}\right)$} & & \\
\hline Pematangsiantar 1 & 4.5 & 2.04 & 0.11 & 3.78 & 0.15 & 0.78 & 0.21 & 1.98 \\
\hline Pematangsiantar 2 & 4.3 & 1.76 & 0.08 & 3.99 & 0.14 & 0.76 & 0.22 & 2.04 \\
\hline Pematangsiantar 3 & 4.4 & 2.16 & 0.12 & 4.04 & 0.23 & 0.87 & 0.34 & 2.11 \\
\hline Criteria & Acid & Low & Low & Low & Low & Low & Low & Medium \\
\hline
\end{tabular}

Note: soil samples were taken randomly from field used as site of experiment

Table 2. Cassava aboveground characters observed, Pematangsiantar, North Sumatra, 20152016

\begin{tabular}{lllllll}
\hline Varieties & Plant height & $\begin{array}{l}\text { branching } \\
\text { height }\end{array}$ & $\begin{array}{l}\text { Stem } \\
\text { diameter }\end{array}$ & $\begin{array}{l}\text { Stem and leaves weigth } \\
\text { (kg/plant) }\end{array}$ \\
\cline { 2 - 6 } & $\ldots \ldots \ldots \ldots \ldots \ldots \ldots \ldots(\mathbf{c m})$ & $\ldots \ldots \ldots \ldots \ldots \ldots \ldots \ldots$ & Basal & Middle & Upper \\
\hline UB1/2 & 254 & 135 & 3.25 & 4.0 & 2.9 & 2.5 \\
UB1472 & 200 & 140 & 3.05 & 3.6 & 2.8 & 2.5 \\
Adira-1 & 208 & 140 & 2.45 & 3.7 & 2.9 & 2.5 \\
Malang 4 & 310 & 254 & 2.75 & 4.3 & 2.7 & 2.3 \\
Cecek ljo & 233 & 74 & 2.61 & 3.5 & 2.4 & 2.0 \\
Farsem & 291 & 118 & 3.16 & 4.2 & 2.8 & 2.3 \\
Gajah & 290 & 95 & 2.50 & 4.1 & 2.7 & 2.3 \\
Ketan Jabung & 225 & 84 & 3.13 & 3.1 & 2.2 & 1.9 \\
Caspro & 189 & 128 & 2.85 & 3.2 & 2.2 & 1.8 \\
Adira-4 & 259 & 106 & 2.58 & 3.8 & 3.0 & 2.6 \\
Malaysia (Local) & 174 & 86 & 2.10 & 3.7 & 2.6 & 1.9 \\
Cikaret (Local) & 253 & 103 & 2.33 & 3.1 & 2.9 & 2.2 \\
LSD 5\% & 52.25 & 51.26 & 0.53 & 0.2 & 0.2 & 0.6 \\
CV (\%) & 15.11 & 29.26 & 13.45 & 3.91 & 4.90 & 5.63 \\
\hline & Note: LSD = Least Significant Difference; CV $=$ Coefficient of Variation &
\end{tabular}

The three existing local varieties which widely planted by farmers were early branching, in fact in some areas in Pematangsiantar, Malaysia genotype is late branching (Table 2). However, in this site of evaluation was also to be early forking. It seems the early forking formation was due to of poor nutrients content, particularly $\mathrm{K}$ (Table 1). This also related to stem cutting origin. Nine varieties from Malang were not to form forking early. But the stem cuttings of three varieties were originated locally, so the poor quality of stem cutting generated from poor nutrient content influencing to the early forking formation.
The early branching type is not only unsuitable for intercropping determination, but also very limited to produce planting materials. Mostly stem cuttings generated below forking formation are used as planting materials. Thus early forking will only be able to produce 2-3 stem cuttings, while late and non-branching type will be able to produce at least 5 stem cuttings. Selecting of stem cutting for planting material is also by considering the diameter of stem. Too large diameter is not preferred by farmers because it is voluminous. The range of stem diameter of $2.5-$ $3.25 \mathrm{~cm}$ is still suitable to be used for planting material (Table 2). Upper portion after forking 
formation, if it was used for stem cuttings will result in new plant with early branching. The only utilization of upper portion of branches with leaves is for feed of animal especially cattle, buffalo and goat as well. Fortunately in and around Siantar and Simalungun (site of experiment) cattle fattening are available abundantly. Therefore no need to worry about the utilization of upper portion of cassava and its leaves is used as green fodder.

During harvesting, cattle owner also collect green fodders as stock feed. Three genotypes introduced from Malang namely UB1/2, UB1472 as well as Adira-1 have very good production of upper portion (Table 2). It means these genotypes were also suitable to be grown as source of green fodder for animal feed. The highest green fodder was produced by Adira-4, however those three genotypes mentioned showed nosignificant difference. There was a fungus incident especially Cercospora heningsii, although not too serious $(<10 \%)$. Fortunately there was no mealy bugs infestation observed, so the growth of cassava canopy performed very well during growing period.

Among twelve varieties, Malang-4 indicated the highest tuber root yield $\left(49,830 \mathrm{~kg} \mathrm{ha}^{-1}\right)$ followed by Farsem variety $\left(41,690 \mathrm{~kg} \mathrm{ha}^{-1}\right)$, and Malaysia Local variety $\left(41,030 \mathrm{~kg} \mathrm{ha}^{-1}\right)$ (Table 3$)$. On the other hand, Ketan Jabung an introduction from Malang for table use was the lowest one, only yielded $20,570 \mathrm{~kg} \mathrm{ha}^{-1}$. The poor root yield in Ketan Jabung was due to root rot diseases. In Malang, Ketan Jabung was mostly planted by farmers in upland at higher altitude with very good drainage. While in site of trial at Siantar with higher rainfall as well as humidity, Kejab to be susceptible to root rot and ultimately yield is reduced due to many rotten roots probably due to poor drainage. The serious root rot incident may be caused by the lower soil $\mathrm{pH}$ ranging from
4.3 to 4.5 , although during the harvest period $\mathrm{pH}$ measurement kit indicated $\mathrm{pH}$ around 5 . However data from laboratory seemed to be more accurate.

\subsection{Farmers Evaluation}

Selection criteria applied by 30 indigenous farmers, five traders and one factory staff during the harvest of variety trial is presented in Table 4. The higher starch content coincided with higher root yield of Malang-4 is very interesting and will benefit factory. So far there is no different factory price of cassava from farmers, although the starch content testing indicated $\mathrm{B}, \mathrm{C}$ or $\mathrm{D}$ but the price are the same, recently paged at $\mathrm{Rp} 650 \mathrm{~kg}$ 1 of fresh cassava. Indeed a level of starch content is very secret in attempts to stipulate a reduction of payment (price conversion) to fresh cassava owner.

Moreover due to better service to cassava owners who sent truck in block log of queue, cash payment after weighing and unloading there is no complain to PT. Bumi Sari Prima so far. There is no answer about the question of if starch content 11, 12, 13, 15, 16, 17, 19, 21, $23 \%$, how is the criteria exactly based on stipulation that $A=22 \%, B=18 \%, C=14 \%$ and $\mathrm{D}=10 \%$. Consequently to measure starch content precisely and accurately, for the harvest in 2017 from this project ther was need to be provided the tool. Simple tool of balance for weighing in air and water needs to be adjusted; however the volume of water has to be decided clearly as $10,20,50,100$ or 200 liter. Then, a shape of water tank whether round or square to put the same volume of water also needs to be considered. To anticipate starch content for the harvest of multi-location trials the balance for weighing in air and water needs not only be one.

Table 3. Cassava underground characters observed, Pematangsiantar, North Sumatra 20152016

\begin{tabular}{llllll}
\hline Varieties & $\begin{array}{l}\text { Root } \\
\text { number }\end{array}$ & $\begin{array}{l}\text { Root } \\
\text { diameter }(\mathbf{c m})\end{array}$ & $\begin{array}{l}\text { Root length } \\
\text { (cm) }\end{array}$ & $\begin{array}{l}\text { Root weight } \\
\text { per plot } \mathbf{( k g )}\end{array}$ & $\begin{array}{l}\text { Root weight per } \\
\text { hectare( kg) }\end{array}$ \\
\hline UB1/2 & 9 & 6.5 & 30.9 & 35.2 & 38,720 \\
UB1472 & 8 & 5.9 & 29.9 & 32.5 & 35,750 \\
Adira-1 & 10 & 6.4 & 28.1 & 33.0 & 36,300 \\
Malang 4 & 13 & 8.0 & 28.9 & 45.3 & 49,830 \\
Cecek ljo & 9 & 5.0 & 27.6 & 17.4 & 19,140 \\
Farsem & 13 & 6.0 & 41.5 & 37.9 & 41,690 \\
Gajah & 10 & 5.9 & 31.0 & 28.6 & 31,460 \\
Ketan Jabung & 9 & 5.8 & 31.1 & 18.7 & 20,570 \\
Caspro & 10 & 6.0 & 31.3 & 25.3 & 27,830 \\
\hline
\end{tabular}




\begin{tabular}{llllll}
\hline Varieties & $\begin{array}{l}\text { Root } \\
\text { number }\end{array}$ & $\begin{array}{l}\text { Root } \\
\text { diameter }(\mathbf{c m})\end{array}$ & $\begin{array}{l}\text { Root length } \\
\text { (cm) }\end{array}$ & $\begin{array}{l}\text { Root weight } \\
\text { per plot } \mathbf{( k g )}\end{array}$ & $\begin{array}{l}\text { Root weight per } \\
\text { hectare( kg) }\end{array}$ \\
\hline Adira-4 & 12 & 6.1 & 31.1 & 24.9 & 27,390 \\
Malaysia (Local) & 12 & 6.3 & 30.9 & 37.3 & 41,030 \\
Cikaret (Local) & 10 & 6.3 & 30.6 & 23.6 & 25,960 \\
LSD 5\% & 1.3 & 0.7 & 1.86 & 9.86 & 9,862 \\
CV (\%) & 8.75 & 7.75 & 4.16 & 22.87 & 22.87 \\
\hline
\end{tabular}

Table 4. Selection criteria applied by indigenous farmers, traders and factory during the harvest of variety trial, 2016

\begin{tabular}{|c|c|c|c|c|c|c|c|c|}
\hline \multirow[t]{2}{*}{ Varieties } & \multicolumn{8}{|c|}{ Indigenous Criteria Selection } \\
\hline & $\begin{array}{l}\text { Tuber } \\
\text { root Yield }\end{array}$ & Branch & $\begin{array}{l}\text { Easy } \\
\text { harvest }\end{array}$ & $\begin{array}{l}\text { Tuber } \\
\text { root size }\end{array}$ & $\begin{array}{l}\text { Root } \\
\text { type }\end{array}$ & $\begin{array}{l}\text { Plant } \\
\text { height }\end{array}$ & Starch & $\begin{array}{l}\text { Total } \\
\text { score }\end{array}$ \\
\hline UB1/2 & 3 & 2 & 5 & 3 & 5 & 4 & $B$ & 20 \\
\hline UB1472 & 2 & 2 & 4 & 3 & 4 & 4 & $B, C, D$ & 19 \\
\hline Adira-1 & 1 & 2 & 3 & 2 & 3 & 3 & $\mathrm{~B}, \mathrm{C}$ & 14 \\
\hline Malang 4 & 5 & 5 & 5 & 5 & 5 & 5 & $B$ & 30 \\
\hline Cecek ljo & 3 & 3 & 4 & 3 & 5 & 3 & C, D & 21 \\
\hline Farsem & 3 & 2 & 3 & 2 & 4 & 3 & $\mathrm{~B}, \mathrm{C}$ & 18 \\
\hline Gajah & 2 & 3 & 2 & 3 & 2 & 2 & B & 14 \\
\hline Ketan Jabung & 3 & 2 & 3 & 3 & 3 & 3 & $B$ & 17 \\
\hline Caspro & 4 & 3 & 4 & 3 & 4 & 4 & $B$ & 22 \\
\hline Adira-4 & 4 & 3 & 4 & 4 & 4 & 3 & C, D & 22 \\
\hline $\begin{array}{l}\text { Malaysia } \\
\text { (Local) }\end{array}$ & 4 & 4 & 4 & 4 & 4 & 4 & $\mathrm{~B}, \mathrm{C}$ & 24 \\
\hline Cikaret (Local) & 3 & 4 & 3 & 3 & 3 & 4 & C & 20 \\
\hline
\end{tabular}

Note: score from 1 to 5 indicating $1=$ very bad, $2=$ bad, $3=$ moderate, $4=$ good, and $5=$ very good. Starch content based on factory criteria October 26, $2016 A=22 \%, B=18 \%, C=14 \%$ and $D=10 \%$

\section{DISCUSSION}

The introduced improved variety Malang-4 produced root yield of $49,830 \mathrm{~kg} \mathrm{ha}^{-1}$ which was $21 \%$ and $92 \%$ higher than the local varieties Malaysia and Cikaret, respectively, suggested that Malang-4 was more adapted than other nine introduced improved varieties. This result was higher than the tuber root yield of cassava harvested in Alfisol soil in Java island regions. The results showed that in the dry land of Alfisol in Gunung Kidul and Bantur of Malang regency, East Java province, Indonesia which was low in potassium, the cassava variety yielded $40 \mathrm{t} \mathrm{ha}^{-1}$ of tubers [7].

The identification of several highyielding, highstarches and/or tasty cassava varieties, that were suitable for industrial processing, animal feeding, for human consumption, more economic, and sustainable cassava production practices had been conducted in several areas in Java and Sumatera islands of Indonesia. Highly promising varieties identified and preferred by farmers include UJ-5, UJ-3, Markonah, Malang 6,
UB 447-2, UB 1/2, Faroka, Bandung, Manggu and Adira 1 [8].

In Genteng of Banyuwangi regency, East Java province, Indonesia, fertilizing $200 \mathrm{~kg}$ of Urea + $150 \mathrm{~kg} \mathrm{SP}-36+100 \mathrm{~kg}$ of $\mathrm{KCl} /$ ha plus 5 tons of manure along with 2 times of piling and weeding can be obtained tuber yield of $60 \mathrm{tha}^{-1}[9,10]$. The addition of organic matter will reduce the weight of the soil, increase aggregate stability and total porosity, soil moisture content and plant productivity [11]. The root yield obtained in the Pematangsiantar of $49,830 \mathrm{~kg} \mathrm{ha}^{-1}$ was higher than those obtained by other studies in Ethiopia using cassava varieties Hawassa-4 (23.93 t/ha), Kello (19.90 t/ha) and Qulle (18.73 t/ha) [12], and on sandy loam soil in Ghana, slightly acidic, low NPK and C-organic, that produced fresh tubers of $43.9 \mathrm{t} \mathrm{ha}^{-1}$ [13] and increased tuber yield by $39.5 \%$ in Nigeria [14].

Starch content is very important indigenous criteria for farmers and traders to know for fair price determination in relation to starch content, although factory feels hesitant to share. Although entering the mid of December 2016 the global 
price of tapioca starch was going to increase almost USD 345 ton $^{-1}$, however fresh price of cassava was not expected to increase. Amazingly, the demand from Java as well as from abroad was not met, due to factory still awaiting for better price entering 2017 to release the stock of tapioca. As consequent, tapioca factory stored the stock so there was no need to process more in order to keep farm gate price low. Parkers et al. [13] reported that in Ghana, cassava starch content produced by several varieties ranged from $21.61-24.66 \%$ which was influenced more by variety than by fertilization. The newly released high yielding varieties can be used as component of input subsidy [15]. Fertilizer N, P and especially $\mathrm{K}$ is really recommended to be applied by by farmers and government policy should encourage farmers to utilized this kind of input $[16,17,18]$. Beside that, planting cassava with good land preparation, suitable time period for plantation, and involvement of young farmers may play a key role in the improvement of technical efficiency for cassava farming [19]. Therefore, it is necessary to enhance the breeding efforts to develope cassava varieties having desirable traits such as increased root, flour, and starch yield, reduced toxicity, reduced pest/disease susceptibility and improved nutrient contents to make flour and starch are highly profitable food products derived from cassava in some part of the world [20].

\section{CONCLUSION}

Among twelve varieties, the improved variety Malang-4 indicated the highest tuber root yield $\left(49,830 \mathrm{~kg} \mathrm{ha}^{-1}\right)$ followed by Farsem variety $\left(41,690 \mathrm{~kg} \mathrm{ha}^{-1}\right)$, and Malaysia Local variety $\left(41,030 \mathrm{~kg} \mathrm{ha}^{-1}\right)$. The bitter taste of Malang 4 was an appropriate character to be developed as starch processing of cassava. Starch content is very important indigenous criteria for farmers and traders to know fairly about pricing in relation with starch content. The higher starch content coincided with higher root yield of Malang-4 is very interesting and will benefit the factory. There was no difference in factory price of cassava from farmers, although the starch content indicated different levels $(B=18 \%, C=14 \%$ or $D$ $=10 \%$ ). The Malang- 4 could be introduced to the local goverment for being grown in a larger areas in the North Sumatera province.

\section{ACKNOWLEDGEMENT}

The authors thank to many parties who help the research undertaken, especially to PT. Bumi Sari
Prima. Thank also goes to Prof. W.H. Utomo, Project Leader UB Malang, Prof. R. Cramb, Drs. J. Newby and D. Smith they are from Agribusiness School University of Queensland and Drs. T.M. Aye and M. Imran Soil Scientists of CIAT for their valuable guidance.

\section{COMPETING INTERESTS}

Authors have declared that no competing interests exist.

\section{REFERENCES}

1. Simatupang P. Increasing the competitiveness of cassava, soybeans and peanuts to increase farmers' income, food security, added value, and foreign exchange earnings. Pages: 1-12. In the Proceedings of the National Seminar on Research Results of Various Nuts and Bulbs in 2012. Bogor Research and Development Center; 2012.

2. National Development Planning Agency. Indonesian economy outlook 2017 global risk challenge. ministry of national development planning agency (Bappenas); 2017.

Available:https://www.bappenas.go.id/inde x.php/download.../9693/.

3. BPS. Statistics Indonesia. Indonesian statistics. Statistical Year Book of Indonesia 1981 to 2014. Central Bureau of Statistics Jakarta Indonesia; 2015.

4. Flach M, Rumawas F. (Eds.). Plant resources of South-East Asia No 9. Plants yielding non-seed carbohydrates. Backhuys Publishers, Leiden. 1996; 237.

5. de Oliveira EJ, Fukuda WMG, de Oliveira1 SAS, Ringenberg R, Silva MR, Souza AS, Silva ALL, Filho MSO, Faria ML, Silva RJS. BRS Novo Horizonte - a new cassava variety for industrial use. Crop Breeding and Applied Biotechnology. 2020;20(2):e28882028

Available:http://dx.doi.org/10.1590/198470332020v20n2c24

6. Howeler RH. The cassava handbook. Centro International de Agricultural Tropical (CIAT) office for Asia. Chatuchak, Bangkok Thailand. 2012;810.

7. Ispandi A, Santoso LJ, Mayar. Fertilization and dynamics of potassium in soil and cassava in dry land Alfisol, In Koes Hartojo el al.(ed). Empowerment of cassava supports national food security and 
community agribusiness development. Balitkabi. 2003;190-201.

8. Utomo WH, Marjuki, Wargiono, Hartoyo K, Suharjo Retnaningtyas E, Santoso D, Wijaya A, Howeler R. Enhancing the adoption of improved cassava production and utilization systems in Indonesia (The ACIAR Cassava Project in Indonesia). Conference: A New Future for Cassava in Asia: Its Use as Food, Feed and Fuel to Benefit the Poor. Proc. 8th Regional Workshop held in Vientiane, Lao PDR. Oct 20-24, 2008. Vientiane, Lao PDR. 2008;490-506.

9. Radjit BS, Nila P, Munip A, Nasir S. Efficient production technology of early maturing cassava in dry land and tidal land with a potential yield of $40-60 \mathrm{t} / \mathrm{ha}$. Balitkabi Technical Report; 2010.

10. Radjit BS, Widodo Y, Saleh N, Prasetiaswati N. Technology to increase productivity and profitability of cassava farming in Ultisol dry land. Food crop science and technology. 2014;9(1):51-62.

11. Yatno $E$. The role of organic matter in improving soil physical quality and crop production. Journal of Land Resources. Journal of Land Resources. 2011;5(1):1123.

12. Misganaw CD, Bayou WD. Tuber yield and yield component performance of cassava (Manihot esculenta) varieties in Fafen District, Ethiopia. International Journal of Agronomy, 2020;1-6. Article ID 5836452.

Available:https://doi.org/10.1155/2020/583 6452

13. Parkes EY, Allotey DF, Lotsu E, Akuffo EA. Yield performance of five cassava varieties under different fertilizer rate. International J. Of Agricultural Sci. 2012;2(5):173-177.

14. Ojeniyi SO, Adejoro SA, Ikotun O, Amusan $O$. Soil and plant nutrient composition, growth and yield of cassava as influenced by integrated application of NPK fertilizer and poultry manure.2012. New York Sci.J. 2012;5(9):62-68.

15. Odunaya AA. Contribution of the "Cassava: Adding Value for Africa"
(C:AVA) project to income generation in Nigeria: The case cassava farmers and processors in Ewekoro Area of Ogun State. A research project submitted to Larenstein University of Applied Sciences In Partial Fulfilment of the Requirements for the Degree of Master of Development, with Specialization in; Rural Development and Food Security. Wageningen. 2012; 49.

16. Biscaye $P$, Clark C, Javaid K, Lawrence A, Neidhart M, Harris KP, Rudder J, Anderson CL, Reynolds T. Agribusiness development clusters, SEZs and incubators: Lessons learned for smallholder-focused agricultural development. EPAR Brief No. 302 Prepared for the Agricultural Development Team of the Bill \& Melinda Gates Foundation. University of Washington. 2015;82.

17. Abula M, Mohammed M. The impact of fertilizers subsidy on cassava production in Nigeria (1986-2010). International Journal of Farming and Allied Sciences; 2013.

Available:www.ijfas.com @2013 IJFAS Journal-2013-2-11/272-276 ISSN 23224134 @2013 IJFAS.

18. Patino MTO, Okechukwu RU, lyangbe C, Osun T. Growth of agro-enterprises in developing countries: The case of cassava processing enterprise in Nigeria. A Research Article in African Journal of Root and Tuber Crops AJRTC. 2013;10(1):6166.

19. Soukkhamthat T, Wong GY. Technical efficiency analysis of small-scale cassava farming in Lao PDR. Asian Journal of Agriculture and Development. 2016;13(1):21-39.

20. Ayetigbo $\mathrm{O}$, Latif $\mathrm{S}$, Abass $\mathrm{A}$, Müller J. Comparing characteristics of root, flour and starch of biofortified yellow-flesh and whiteflesh cassava variants, and sustainability considerations: A review. Sustainability. 2018;10:3089.

DOI: $10.3390 /$ su10093089

(C) 2021 Widodo et al.; This is an Open Access article distributed under the terms of the Creative Commons Attribution License (http://creativecommons.org/licenses/by/4.0), which permits unrestricted use, distribution, and reproduction in any medium, provided the original work is properly cited.

Peer-review history:

The peer review history for this paper can be accessed here: https://www.sdiarticle4.com/review-history/73351 